J. Perinat. Med. 14 (1986) 435

\section{The potential distribution generated by the fetal heart at the maternal abdomen}

\author{
Thom F. Oostendorp ${ }^{1}$, Adriaan van Oosterom ${ }^{1}$, Henk W. Jongsma ${ }^{2}$, and Pieter
} W. J. van Dongen ${ }^{2}$

${ }^{1}$ Laboratory of Medical Physics and Biophysics and

${ }^{2}$ Department of Obstetrics and Gynecology, St. Radboud Hospital University of Nijmegen, The Netherlands

\section{Introduction}

The pathways along which the electrical currents generated by the fetal heart are conducted to the surface of the maternal abdomen are not known. As a consequence, in recording the fetal electrocardiogram (FECG) it is hard to predict where electrodes should be placed in order to obtain an optimal signal. The FECG varies with gestation [2], and there is a large interindividual variation in the amplitude of the FECG and in the optimal recording site among subjects of the same gestational age.

The decrease in amplitude around the 30th week has been ascribed to the isolating effect of the vernix caseosa, which surrounds the fetus at that time [2].

Two different hypotheses concerning the conduction of the electrical signal of the fetal heart are found in literature. Based on the distribution of the FECG on the maternal abdomen, RocHe and Hon [8] postulate that the electrical signal is propagated mainly by low-impedance pathways, such as the umbilical cord-placenta pathway and the fetal mouth-amniotic fluid pathway. TACCARDI [9] on the other hand describes a case which resembles more the conduction of the electrical signal through a homogeneous volume. OLDENBURG and MACKLIN [6]

\section{Curriculum vitae}

THOM OOSTENDORP was born in 1959. He received the M.S. degree in physics from the University of Nijmegen, The Netherlands, in 1983. In 1984 he worked on automatic recognition of CTG patterns at the St. Radboud Hospital in Nijmegen. Since September 1984 he has been employed at the Labora-

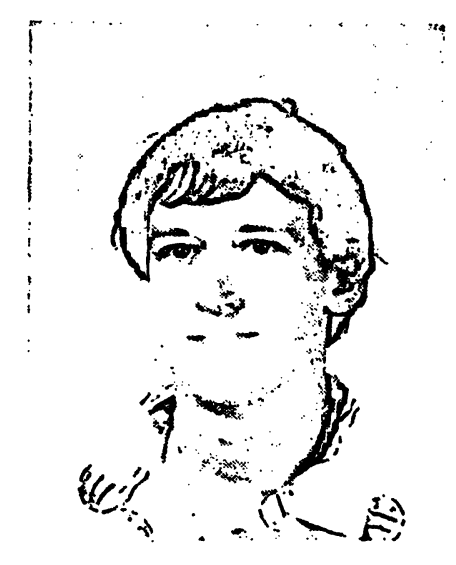
tory of Medical Physics and Biophysics of the University of Nijmegen, where he is working on a project on abdominal FECG's.

suggest that there is uniform volume conduction during the beginning of the second half of gestation, but that preferred pathways play a dominant role in the signal transmission during the last weeks of gestation.

However, all these theories are based on recordings from just a few simultaneous leads, or on signals successively recorded at different sites. To test a model of the volume conductor based on a detailed description of the geometry involved, simultaneous potential measurements on many sites are needed. 
This paper presents the methods for obtaining the potential distribution generated by the fetal heart at the maternal abdomen from multi-lead recordings, and for a 3-dimensional description of the geometry of the volume conductor, as observed by means of echography. In future studies the theoretical potential distribution derived from this geometrical model will be confronted with the recorded potential distribution.

\section{Material and methods}

Pregnant volunteers with uncomplicated pregnancies are examined once every two weeks from 20 weeks of gestation onward. At this stage 3 pregnancies have been followed.

At these sessions the electrical potential distribution at the maternal abdomen is recorded. Real time echography is used for and after the recording to check whether the fetus has moved during the recording. Echography is also used to obtain a detailed description of the geometry.

\subsection{Geometry}

To obtain a detailed description of the geometry, transverse scans are made every $2 \mathrm{~cm}$ across the maternal abdomen, using a compound echo scanner (Diasonograph NE4200, ultrasound probe $2.5 \mathrm{MHz}$ ).

The video display image is copied using a hardcopy unit (Tektronics 4632). The contours of the relevant tissues (fetal head and body, placenta and uterus) and the place of the fetal heart are documented visually from these hardcopies. The extremeties of the fetus are not included. Real time echoscopy is used to support the identification of the various parts of the anatomy. In addition to the echography the contours of the maternal abdomen are recorded by applying a flexible ruler at $4 \mathrm{~cm}$ intervals.

The contours are fed into a PDP-11 computer using a graphics tablet. From these contours the surfaces of the anatomical compartments are formed by a triangulated representation [5].
This is done separately for the fetus, placenta, uterus and maternal abdomen.

The overall accuracy of this technique is $1 \mathrm{~cm}$.

\subsection{Fetal body surface maps (FBSM)}

The abdominal FECG is recorded on 32 leads simultaneously. The electrode placement is shown schematically in figure 1 . All potentials are measured with respect to the reference electrode (placed at the right thigh).

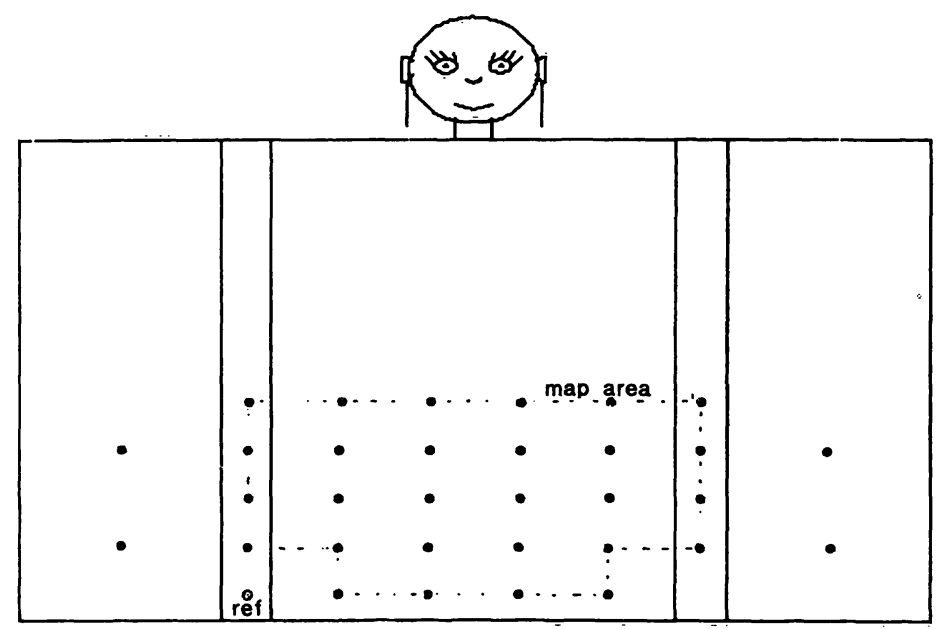

Figure 1. Electrode positions at maternal abdomen and back. The middle sector represents the maternal abdomen, and the outer sectors represent the left and right half of the maternal back. The area in which the fetal body surface maps in this paper are plotted is within the dotted line.

\subsubsection{Recording system}

The recording system consists of the following components (figure 2):

- a low noise buffer amplifier for the reference electrode, 32 low noise differential pre-amplifiers and 32 isolation amplifiers. The total gain per channel is 10000 , the common mode rejection is $80 \mathrm{~dB}$ and the noise measured with short circuited inputs is $2 \mu \mathrm{V}$ peak to peak;

- 32 low-pass 4th order Bessel filters, with a cutoff frequency of $250 \mathrm{~Hz}$;

- 32 sample and hold circuits;

- a 32 channel A-D converter with 12 bit resolution, operating at $500 \mathrm{~Hz}$;

- a DEC 11/34 computer with peripherals. 


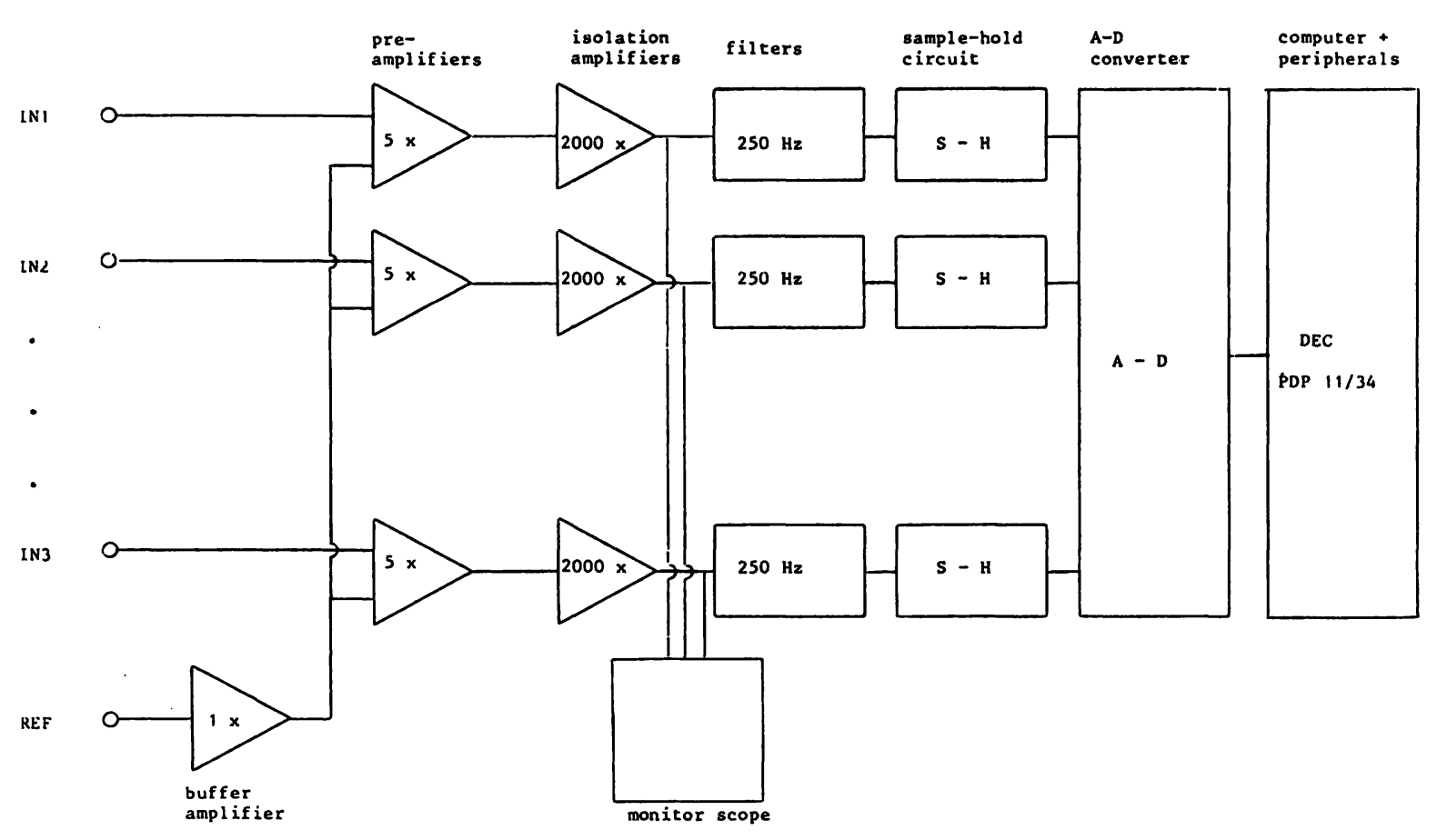

Figure 2. Schematic diagram of the recording equipment.

This recording system provides a 32 leads recording, digitized within a range of -1 to $1 \mathrm{mV}$, having a resolution of $0.5 \mu \mathrm{V}$, sampled at 500 $\mathrm{Hz}$ [4]. At each session a recording of 45 seconds is made and stored on disc for further processing.

\subsubsection{Signal quality}

The total noise in the recordings varies from 3 to $10 \mu \mathrm{V}$ peak to peak. In many leads no fetal signal can be discerned in the noise. Because of this, the recording of just one fetal heart beat does not yield a reliable potential distribution. To improve the signal to noise ratio, a time coherent averaging technique is used. The procedure to obtain average fetal complexes in the different leads consists of the following successive steps (table I).

\subsubsection{Signal processing}

A digital $2 \mathrm{~Hz}$ high-pass filter is applied to all leads to reduce low frequency disturbance, caused for example by the maternal breathing.
Table I. Flowchart of procedure for obtaining multilead average fetal complexes.

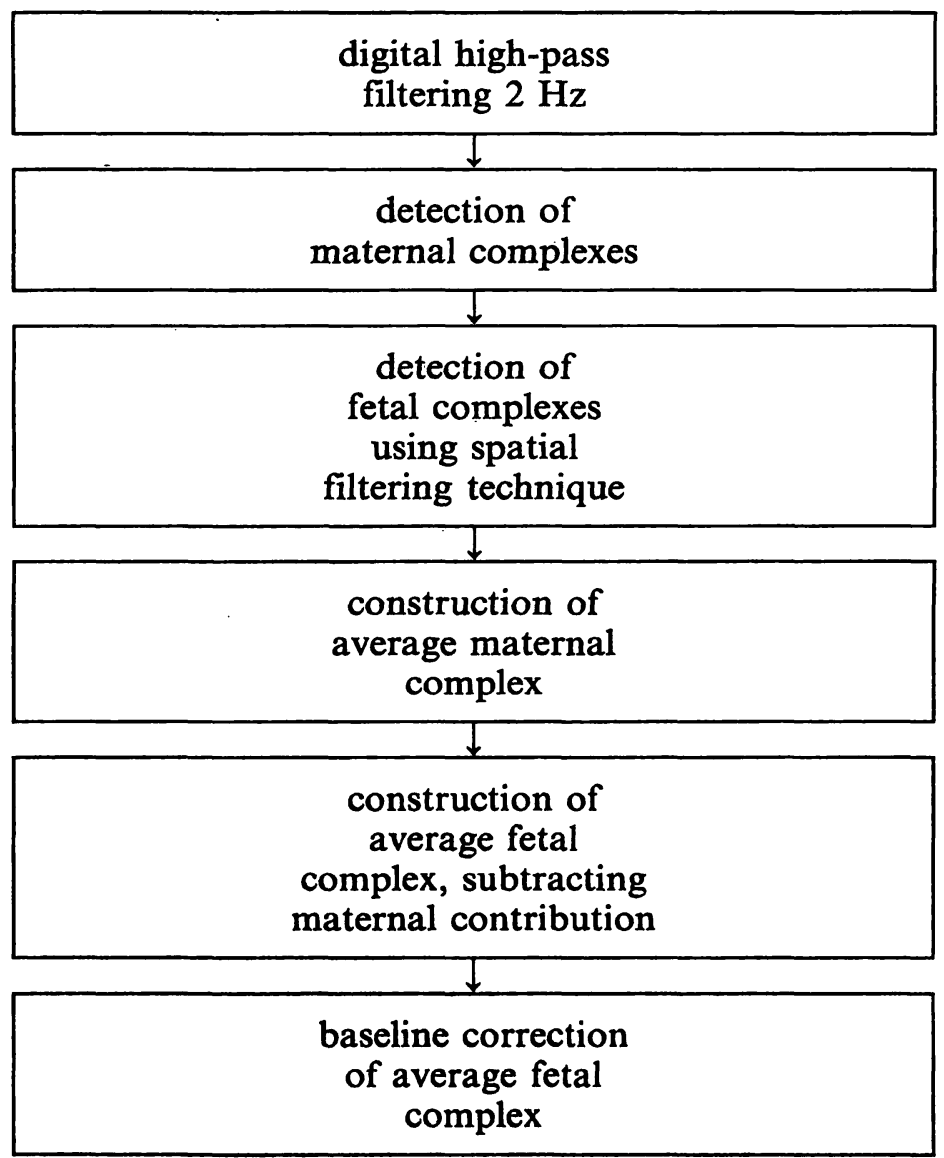




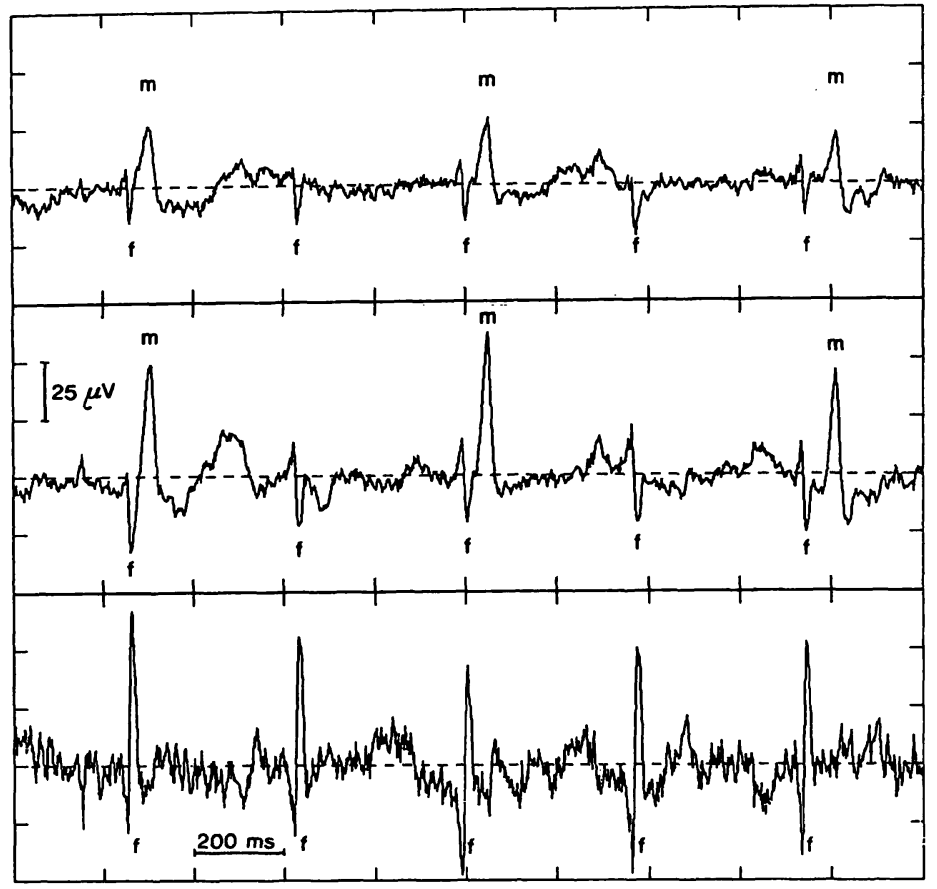

Figure 3. Upper traces: examples of 2 of the 32 recorded signals at 26 weeks (electrode positions 16 and 20); lower trace: "spatial filter output" resulting from the spatial filtering technique to suppress the maternal component and maximize the fetal component.

A lead with a prominent maternal ECG is selected to provide a trigger indicating the maternal complexes. The trigger moment is defined as the moment where the first derivative of the signal reaches it's maximum or minimum, whichever occurs first.

A spatial filtering technique [7] is used to obtain a signal, from which the maternal contribution has been removed, and in which the fetal contribution has been maximized. This signal is a well chosen linear combination of the recorded signals. We will refer to this linear combination further as the "spatial filter output". The spatial filter output is used to provide a trigger for the fetal complexes. Figure 3 shows a segment of two of the 32 recorded signals, as well as the spatial filter output.

To perform this technique, one fetal complex has to be identified in the original recording. If no fetal complex is visible in any of the recorded leads, this computer processing technique is not possible. In our registrations thus far, fetal complexes were visable in $80 \%$ of the cases.

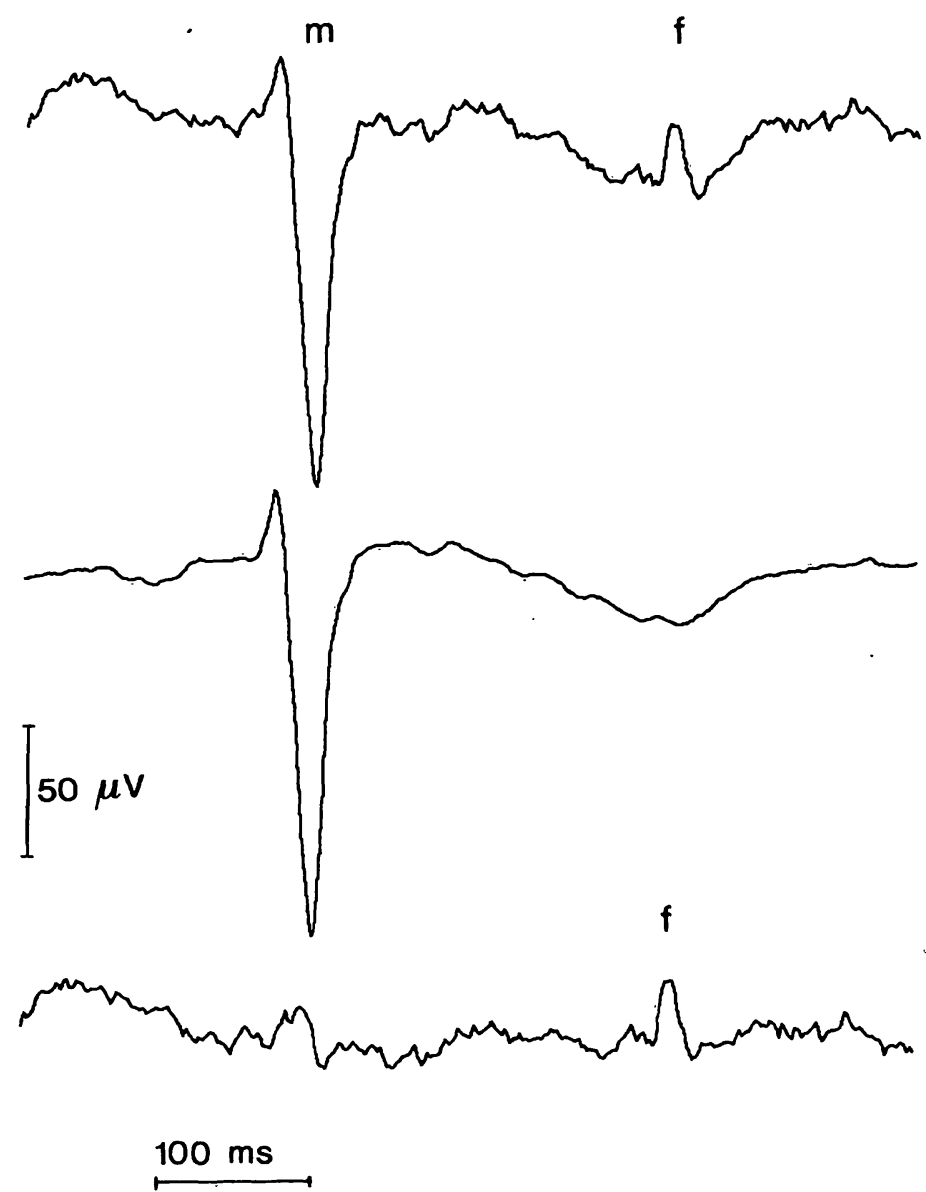

Figure 4. Example of substraction of maternal contribution.

upper trace: one lead showing a maternal (m) and a fetal $(f)$ complex.

middle trace: average maternal complex in same lead.

lower trace: signal after subtraction of the average maternal complex.

Using the maternal trigger average maternal complexes are determined by means of time coherent averaging performed in all leads. The average maternal complexes will be used to suppress the maternal contribution in each lead.

In a similar way, an average fetal complex is determined using the fetal trigger: A recording of 45 seconds contains typically some 80 to 100 fetal complexes. After straight forward averaging of such a number of complexes, a considerable amount of maternal ECG may still be present in the average fetal complex. To overcome this, the maternal contribution is suppressed by subtracting the average maternal complex around each maternal trigger. This is done in each lead separately, using the average 
maternal complex of that specific lead. The corrected signal is then included in the averaging procedure for the fetal complexes. Figure 4 demonstrates this subtraction in one lead.

If a fetal complex coincides with a maternal QRS-complex, it is yet excluded from averaging, because even after subtraction of the average maternal complex relatively small changes in QRS amplitude or the inevitable jitter within the sampling interval of $2 \mathrm{~ms}$ may result in an unacceptably large remainder in the average fetal complex [1]. Coincidence is defined as a maternal trigger moment within less than 120 ms from the fetal trigger moment.

Finally, a baseline correction of the averaged fetal complexes is performed in each lead. To do so, the beginning and the end of a QRS complex are marked interactively. Next, the averages of the samples in a window of $20 \mathrm{~ms}$ before the beginning and in a window of $20 \mathrm{~ms}$ after the end of the QRS complex are determined. A linear ramp is subtracted from the signal in such a way that in the resulting signal both averages will be zero.

In the resulting simultaneous average fetal complexes the noise is reduced to 1 to $2 \mu \mathrm{V}$ peak to peak.

\subsubsection{Presentation of the potential distribution}

The average fetal complexes may be plotted at a map of the sites where they were recorded. To observe the relationship between the various potential values at any given time instant another representation is used: the body surface map [10]. In a body surface map the complete potential distribution on the body surface at one specific moment during the cardiac cycle is plotted by means of e.g. a color scale.

In the present study a map of the potential distribution at the maternal abdomen generated by the fetal heart will be called a fetal body surface map (FBSM). In the FBSM's shown the maternal abdomen is projected on a flat

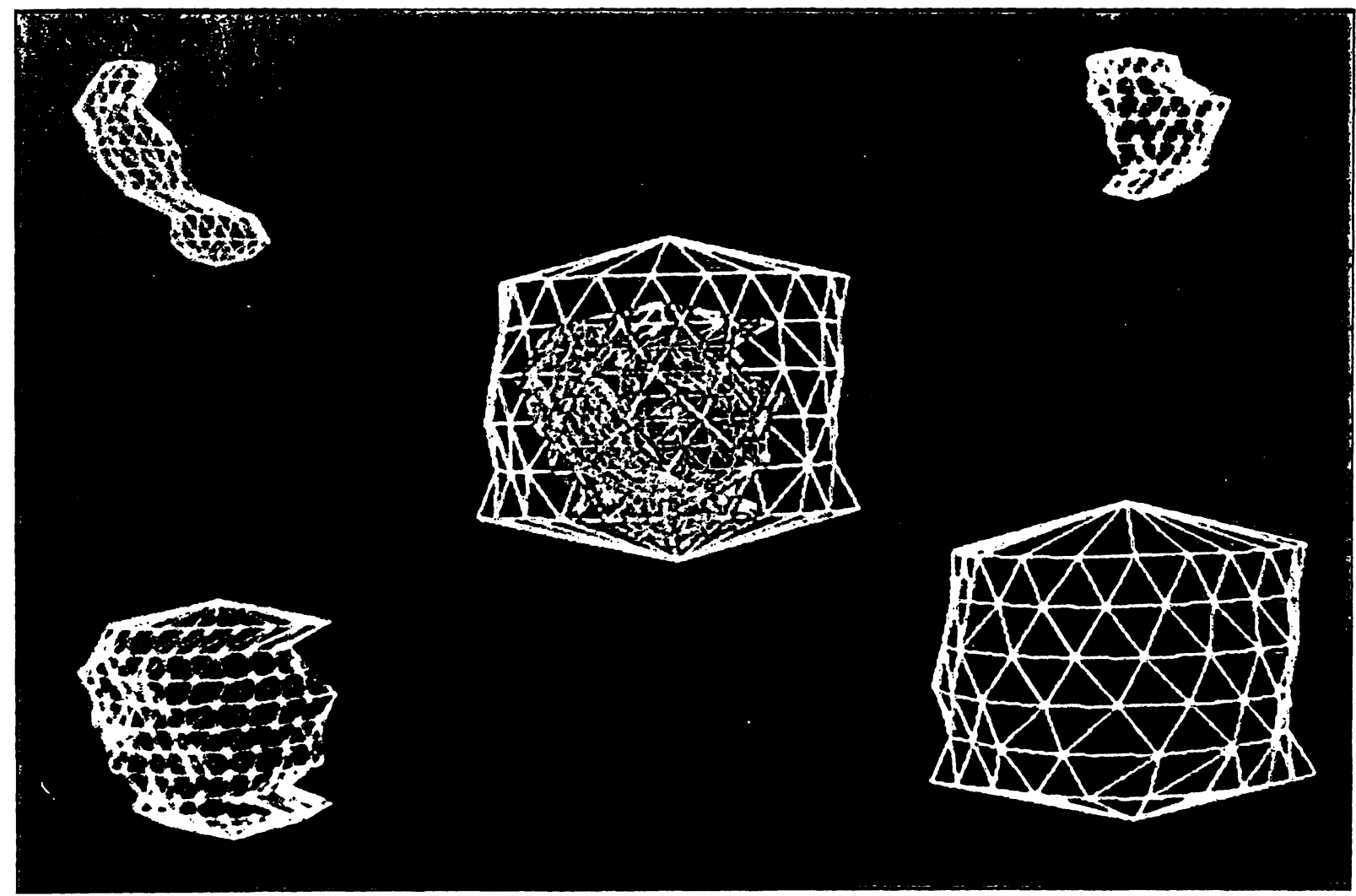

Figure 5. Triangulated representation of the feto-uterine geometry observed in a subject of 40 weeks gestation (frontal view). The fetus, placenta, uterus and maternal abdomen are shown separately and combined. 

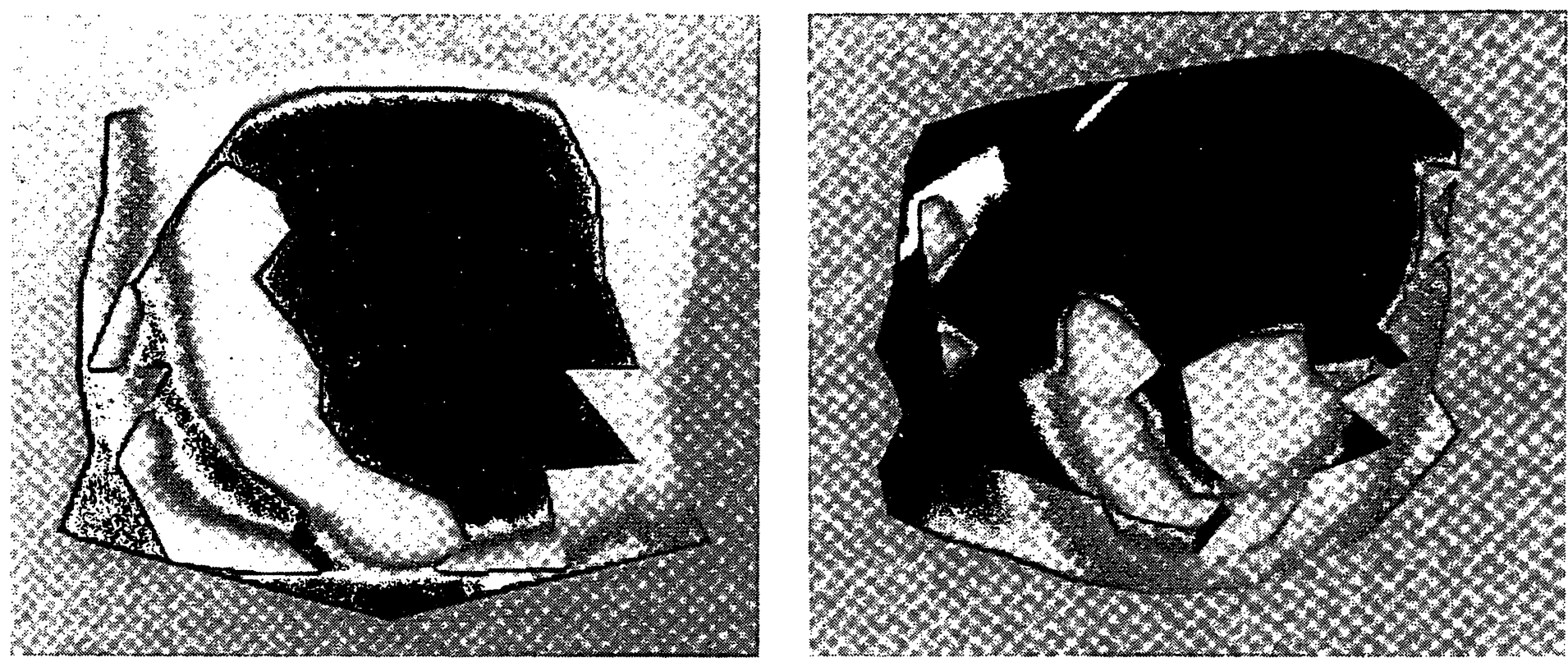

Figure 6. a) Shaded version of triangulated representation of fetus and maternal abdomen observed in a subject of 40 weeks gestation (frontal view). The front of the surface representing the maternal abdomen has been removed to show the fetus. b) idem, oblique frontal view.

surface, corresponding to the "map area", as indicated in figure 1. At each electrode the potential at a specific moment during the fetal cardiac cycle is taken from the average fetal complex; the potential distribution can be plotted after bilinear interpolation [3].

\section{Results}

In figure 5 an example is shown of the triangulated representation of the feto-uterine geometry, observed in a subject of 40 weeks gestation. The fetus, placenta, uterus and maternal abdomen are shown separately and combined.

Using a computer, more realistic views from any point in space can be generated from this representation, as shown in figure 6.

Figure 7 shows the average fetal complexes of an individual at 26 weeks of gestation, plotted at the sites where they have been recorded. Each average complex includes 56 fetal complexes at that site. The vertical lines in this figure represent the trigger moment of the spatial filter output. This moment is arbitrarily called time $=0$ for reference purposes in the following figures. This figure indicates that the form of the fetal complex varies with the recording site.

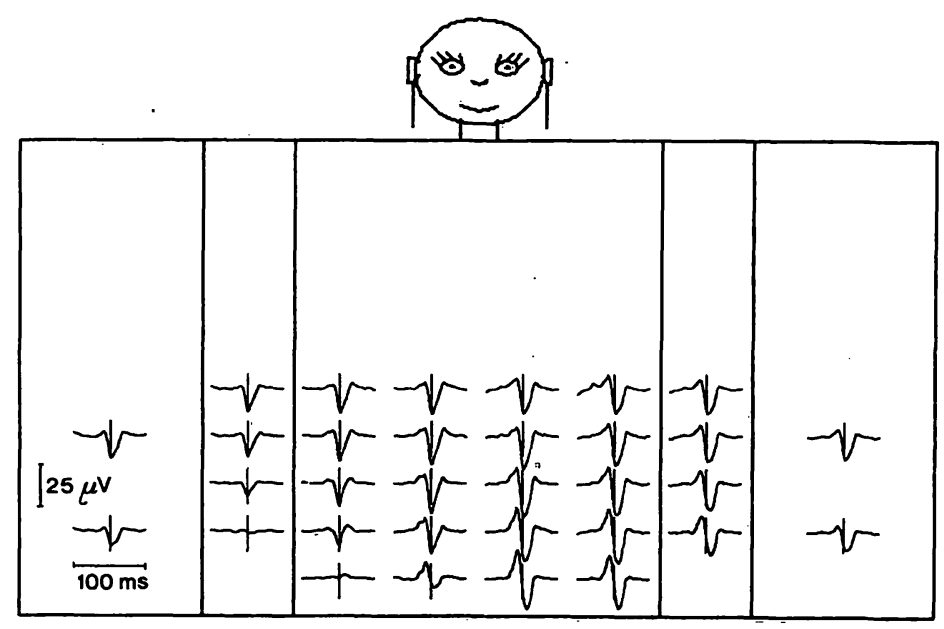

Figure 7. The 32-lead average fetal QRS-complex of a subject at 26 weeks gestation. Each lead is plotted at its recording site. The vertical lines indicate the trigger moment.

Figure 8 shows the FBSM of the same individual at one specific moment during the fetal cardiac cycle $(t=-2 \mathrm{~ms})$. The pótential is plotted in a colour scale.

Figure 9 shows the FBSM of the same individual at subsequent moments during the fetal cardiac cycle. Figures 8 and 9 demonstrate that the maximum and minimum of the potential distributions do not have a fixed location, and that they are not always within the area covered by the abdominal electrodes. 


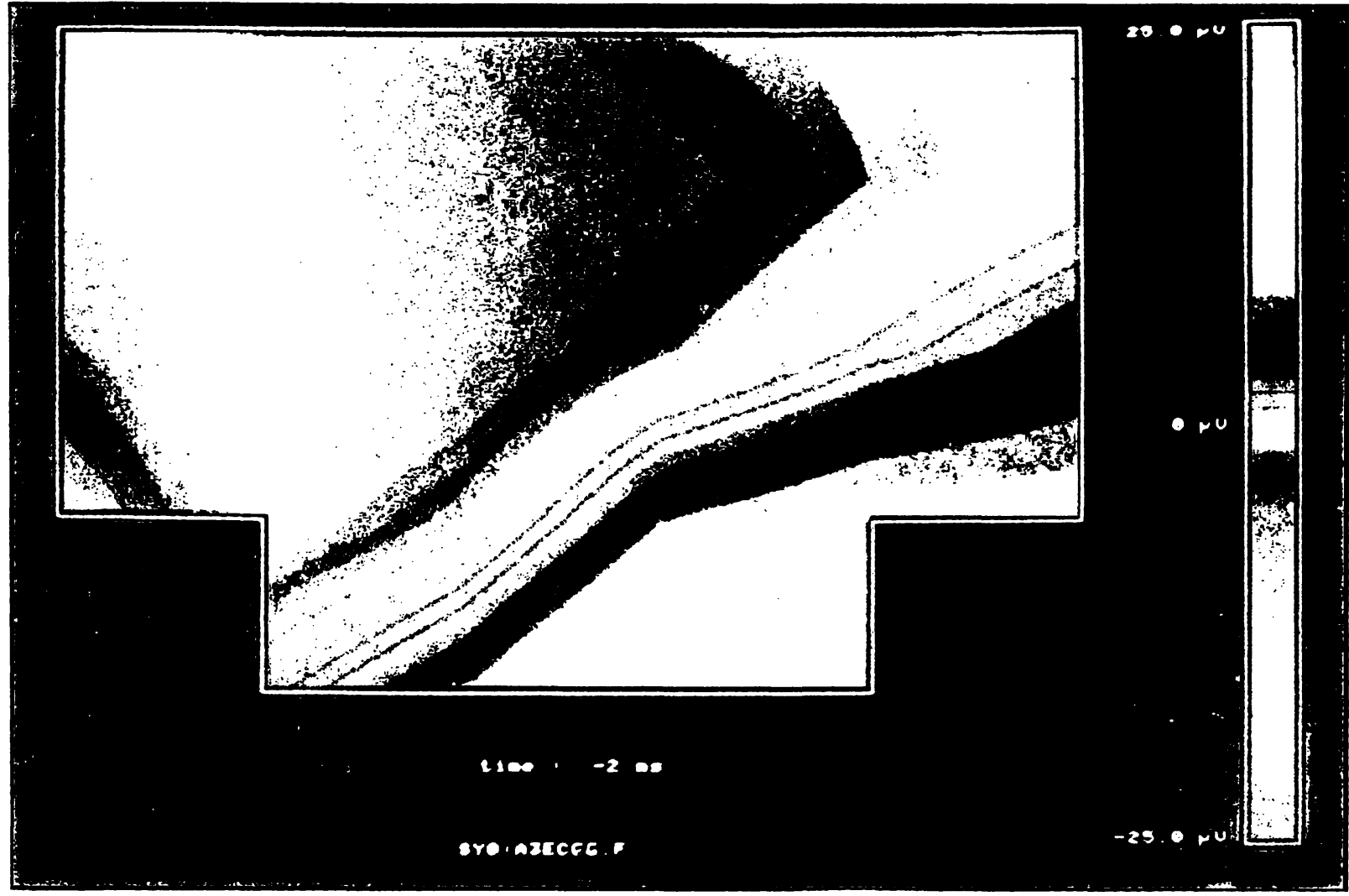

Figure 8. Fetal body surface map at one specific moment during the fetal cardiac cycle of a subject at 26 weeks of gestation. The time is indicated with respect to the trigger moment. The potential distribution is plotted in colour scale, deep blue representing $-25 \mu \mathrm{V}$ and deep red representing $+25 \mu \mathrm{V}$. The bar at the right defines the color scale.

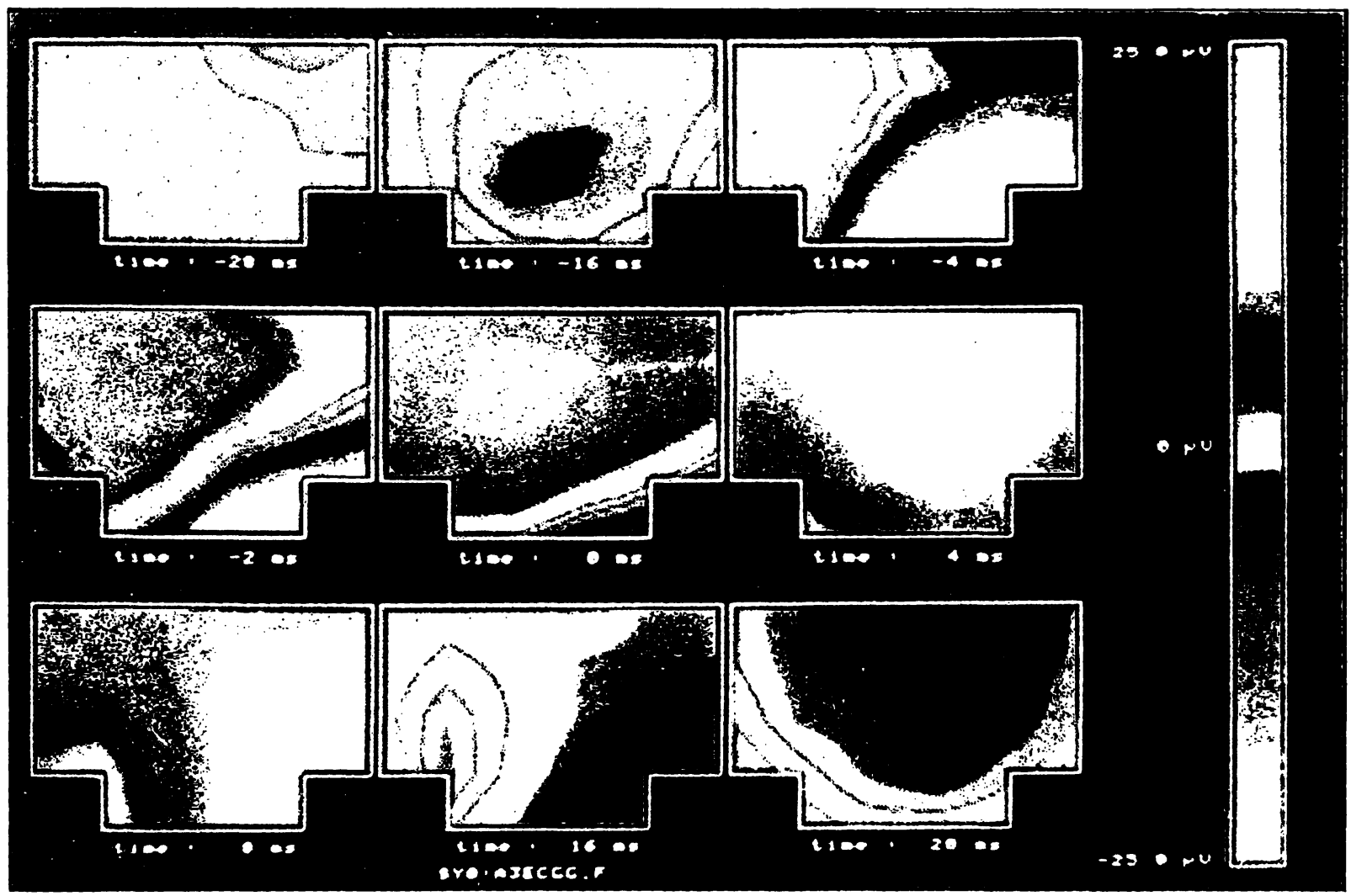

Figure 9. Fetal body surface maps at successive moments during the fetal cardiac cycle from 28 ms before (upper left) to $20 \mathrm{~ms}$ (bottom right) after the trigger moment, of a subject at 26 weeks of gestation. 


\section{Discussion}

A method has been presented to record the intrauterine anatomy (uterus, placenta, fetus) in three dimensions, and to record the complete potential distribution generated by the fetal heart at the maternal abdomen as a function of time.

In a future study a mathematical model will be made to explain the measured potential distribution in terms of volume conduction, both qualitatively and quantitatively. This model will include the detailed description of the geometry as presented in this paper. The recorded potential distribution will be used to verify the model.

The material studied thus far shows that the positions of the extremes of the potential distribution are not fixed during the cardiac cycle, but move over the maternal abdomen (figure 9). This suggests that the depolarization of the fetal heart has to be described by an equivalent source with the complexity of at least a rotating dipole.

This observation is not in agreement with the "low-impedance pathways" model as described in the introduction, which would yield a physical dipole source of fixed position and orientation and hence would produce fixed places of the potential extremes. In such a model the form of the fetal complexes would be the same at all sites, which is contradicted by figure 7 .

Furthermore it has been demonstrated that the extremes of the potential distribution at the maternal abdomen are not always within the range of abdominal electrodes. The clinical implication of this observation is that a FECG with maximum amplitude is sometimes obtained between electrodes which are placed at the edge or outside the abdominal range.

\section{Summary}

The pathways along which the electrical currents generated by the fetal heart are conducted to the surface of the maternal abdomen are not known. As a consequence, in recording the fetal electrocardiogram (FECG) it is hard to predict where electrodes should be placed in order to obtain an optimal signal. The amplitude of the FECG varies with gestation [2], and there is a large interindividual variability in the amplitude of the FECG and in the optimal recording site among subjects within the same gestational age. Attempts have been made to explain these phenomena in terms of volume conduction $[6,8,9]$.

In this research the complete potential distribution on the maternal abdomen is studied in connection with the geometrical configuration of the electrical source (fetal heart) and the volume conductor (surrounding tissues). For a small group of pregnant women the abdominal FECG is recorded simultaneously in 32 leads during a period of about one minute, once every two weeks from 20 weeks of gestation onwards. A spatial filtering technique which combines information of all 32 leads [7] is used to provide a trigger of the fetal QRS complexes. Using this trigger, an average fetal complex is constructed for each lead by time coherent averaging, after subtraction of the maternal contribution. These average fetal complexes are combined to plot the complete potential distribution generated by the fetal heart at the

maternal abdomen (fetal body surface map, FBSM) at any given time instant during the fetal cardiac cycle. At these recording sessions the geometry is carefully quantified by making transverse scans every $2 \mathrm{~cm}$ with a compound echo scanner. The contours of fetal head and body, the placenta and the uterus are manually drawn on hardcopies of the video display images. Real time echoscopy is used to support the identification of the geometry. The contours are fed into a computer using a graphics tablet. The three dimensional surfaces of fetus, placenta and uterus are separately represented by a triangulation of the respective contour lines.

Figures 5 and 6 show an example of the triangulated representation of the recorded geometry. Figure 7 shows the average fetal complexes of an individual at 26 weeks of gestation, plotted at the site where they have been recorded. Each average complex includes 56 fetal complexes at that site. Figure 9 shows the FBSM derived from these average complexes, at subsequent moments during the fetal cardiac cycle.

In a future study a mathematical model based on the recorded geometry will be made to explain the measured potential distribution in terms of volume conduction. The material presented shows that the extremes of the potential distribution are not fixed during one fetal cardiac cycle, suggesting an equivalent electrical source with the complexity of at least a rotating current dipole.

Keywords: Echography, electrocardiography, mathematical model, volume conduction. 
Zusammenfassung

\section{Potentialverteilung der fetalen Herzströme am mütter- lichen Abdomen}

Es ist nicht bekannt, über welche Leiter die vom fetalen Herzen erzeugten Potentiale an die Oberfläche des mütterlichen Abdomen gelangen. Daher ist es schwierig, die Elektroden bei der Ableitung des fetalen EKG's (FEKG) richtig bzw. so zu plazieren, daß ein optimales EKG erhalten wird. Die Amplitude des FEKG's variiert mit der Schwangerschaftsdauer [2]. Darüber hinaus gibt es eine große interindividuelle Variabilität der FEKG-Amplitude sowie der optimalen Ableitungspunkte bei Feten mit gleichem Gestationsalter. Um diese Phänomene zu erklären, wird auf die unterschiedliche Volumenleitfähigkeit hingewiesen $[6,8,9]$.

In der vorliegenden Studie haben wir die komplette Potentialverteilung auf dem mütterlichen Abdomen in Verbindung mit der Geometrie der elektrischen Quelle (fetales Herz) und des Volumenleiters (umgebendes Gewebe) untersucht. Bei einem kleinen Kollektiv schwangerer Frauen wurde ab der 20. Woche in zweiwöchigen Abständen über ca. 1 Minute das FEKG mit 32 Ableitungen simultan aufgezeichnet. Ein räumlicher Filter, der die Informationen von allen 32 Abteilungen kombinierte [7], lieferte den Trigger der fetalen QRS-Komplexe. Nach Ausblendung des mütterlichen EKG's wurde für jede Ableitung durch zeitlich kohärentes Mitteln ein gemittelter fetaler Komplex gebildet. Diese wurden zusammengestellt und als komplette Potentialverteilung des fetalen Herzens auf dem mütterlichen Abdomen (Fetal Body Surface Map, FBSM) zu jedem beliebigen Zeitpunkt des fetalen Herzzyklus ausgedruckt.
Während der Aufzeichnungen wurden mit einem Compound-Scanner in Abständen von $2 \mathrm{~cm}$ transversale Schnitte durchgeführt, um die Geometrie möglichst genau zu quantifizieren. Die Umrisse von fetalem Kopf und Körper sowie von Plazenta und Uterus wurden manuell auf Hartkopien zur Videodarstellung aufgezeichnet. Um die Identifizierung der geometrischen Strukturen zu erleichtern, wurde die Realtime-Sonographie eingesetzt. Die Umrißmaße wurden mit eine GrafikTablett in den Computer eingegeben. Die Darstellung der Oberflächen von Fet, Plazenta und Uterus erfolgte getrennt voneinander und als dreidimensionale Abbildung.

Die Abbildungen 5 und 6 zeigen ein Beispiel für die dreidimensionale Darstellung der aufgezeichneten Geometrie. Abbildung 7 zeigt die gemittelten fetalen Komplexe eines Feten der 26. Schwangerschaftswoche, und zwar an der Stelle, wo sie abgeleitet wurden. Jeder Mittelwert beinhaltet 56 fetale Komplexe. Abbildung 9 zeigt die "FBSM", erstellt aus den gemittelten Komplexen in der zeitlichen Abfolge eines fetalen Herzzyklus.

In einer weiteren Arbeit soll ein mathematisches Modell, basierend auf der aufgezeichneten Geometrie, erstellt werden, um die gemessene Potentialverteilung als Funktion der Volumenleitfähigkeit erklären zu können.

Das vorliegende Material zeigt, daß die Extreme der Potentialverteilung während eines fetalen Herzzyklus nicht festgelegt sind. Man muß annehmen, daß eine äquivalente elektrische Quelle vorliegt, die mindestens die Komplexität eines rotierenden Dipols hat.

Schlüsselwörter: Elektrokardiographie, mathematisches Modell, Sonographie, Volumenleitung.

\section{Résumé}

Distribution potentielle sur l'abdomen maternel engendrée par le ceeur foetal

On ne connaît pas les circuits le long desquels les courants électriques générés par le cœur fœetal sont conduits à la surface de l'abdomen maternel. Il en découle que lorsque l'on enregistre l'électrocardiogramme fotal (FECG), il est difficile de prévoir où placer les électrodes pour obtenir un signal optimal. L'amplitude du FECG est variable avec la gestation [2], et il existe une grande variabilité interindividuelle au niveau de l'amplitude du FECG ainsi qu'au niveau de l'emplacement d'enregistrement optimal par les sujets de même âge gestationnel. On a fait des essais pour expliquer ces phénomènes en termes de conduction volumétrique $[6,8,9]$.

Dans cette recherche, on a étudié la distribution potentielle complète sur l'abdomen maternel en connection avec la configuration géométrique de la source électrique (le cœur fœtal), et avec le conducteur volumique (les tissus environnants). Sur un petit groupe de femmes enceintes, le FECG abdominal est enregistré simultané- ment au niveau de 32 électrodes pendant une période d'environ une minute, une fois tous les 15 jours à partir de 20 semaines de gestation. On utilise, pour assurer un déclenchement des complexes QRS fotaux, une technique de filtration spatiale qui combine les informations de l'ensemble des 32 électrodes [7]. En utilisant cette initiation, on construit un complexe fœtal moyen pour chaque électrode par moyennage temporel cohérent, après soustraction de la contribution maternelle. On combine les complexes fœtaux moyens pour tracer la distribution potentielle complète générée par le cœur fotal sur l'abdomen maternel (carte de la surface corporelle fotale, FBSM) à chaque instant au cours du cycle cardiaque fotal.

$\mathrm{Au}$ cours de ces séances d'enregistrement, on quantifie soigneusement la géométrie à l'aide de coupes transversales tous les $2 \mathrm{~cm}$ réalisées par une sonde échographique. On trace manuellement, sur des photocopies des images de l'appareillage vidéo, les contours de la tête fœtale et du corps, le placenta et l'utérus. On utilise 
l'échoscopie en temps réel pour aider l'identification de la géométrie. Les contours sont fournis à un ordinateur à l'aide d'une table graphique. On représente séparément par triangulation des lignes de contours respectifs les surfaces en trois dimensions du fœtus, du placenta et de l'utérus.

Les figures 5 et 6 montrent un exemple de la représentation triangulée de la géométrie enregistrée. La figure 7 montre les complexes fœtaux moyennés d'un individu à 26 semaines de gestation tracés au niveau du site d'enregistrement. Chaque complexe moyenné inclut 56 complexes fœtaux à ce site. La figure 9 montre la FBSM dérivée de ces complexes moyennés, successivement au cours du cycle cardiaque fœtal.

Dans une étude ultérieure, il faudra réaliser un modèle mathématique basé sur la géométrie enregistrée pour expliquer la distribution potentielle mesurée en terme de conduction volumétrique.

Le matériel présenté montre que les extrêmes de la distribution potentielle ne sont pas fixes au cours d'une cycle cardiaque fœtal, ce qui suggère une source électrique équivallente avec la complexité d'au moins un dipôle de courant rotatoire.

Mots-clés: Conduction volumétrique, échographie, électrocardiographie, modèle mathématique.

Acknowledgements: The authors wish to thank A. J. Crevels, A. Heringa, G. J. Huiskamp and G. J. H. UiJen for their help in this research.

\section{References}

[1] Bemmel JH van, L Peeters, SJ Hengeveld: Influence of the maternal ECG on the abdominal fetal ECG complex. Am'J Obstet Gynecol 102 (1968) 556

[2] Bolte A: Zur Ableitung und Bewertung fetaler Herzaktionspotentiale bei schwangeren Frauen. Arch Gynecol 194 (1961) 594

[3] HeRInga A, GJH UiJen, RTH VAN DAM, JPJ DE VALK: The display of body surface maps. In: vaN DAM RTH, A VAN OOSTEROM: Electrocardiographic body surface mapping. Martinus Nijhoff, Dordrecht 1986

[4] Heringa A, GJH UiJen, RTH van Dam: A 64channel system for body surface potential mapping. In: ANTAloczy Z, I PréDA: Electrocardiology '81. Excerpta Medica, Amsterdam 1982

[5] Keppel E: Approximating complex surfaces by Triangulation of contour lines. IBM J Res Develop 19 (1975) 2

[6] Oldenburg JT, M Macklin: Changes in the conduction of the fetal electrocardiogram to the maternal abdominal surface during gestation. Am J Obstet Gynecol 129 (1977) 425
[7] OOSTERom A van: Spatial filtering of the FECG. J Perinat Med, this issue

[8] RocHE JB, EH HoN: The fetal electrocardiogram. V. comparison of lead systems. Am J Obstet Gynecol 92 (1965) 1149

[9] TACCARDI B: The choice of leads in fetal electrocardiography. In: CrosignaNI PG, G PARDI: Symposium on fetal evolution during pregnancy and labour. Academic Press, New York 1971

[10] TaCCARDi B, L DE AMbroggi, C Viganotri: Bodysurface mapping of heart potentials. In: NeLSON CV, DB GselowITZ: The theoretical basis of electrocardiography. Clarendon Press, Oxford 1976

Dr. Thom F. Oostendorp

Laboratory of Medical Physics and Biophysics University of Nijmegen Geert Grooteplein Noord 21 $6525 \mathrm{EZ}$ Nijmegen

The Netherlands 